\title{
Manangement of Rejang Tribe Local Wisdom in Environmental Education
}

\author{
Badeni Badeni; Sri Saparahayuningsih \\ Universitas Bengkulu, Indonesia \\ http://dx.doi.org/10.18415/ijmmu.v9i2.3334
}

\begin{abstract}
Understanding the local wisdom becomes important in managing natural resources and conserving the environment. The purpose of this research is to revitalize and preserve the local wisdom of the indigenous community in Bengkulu. The benefits of this research will be used for the revitalization and preservation of local wisdom and revitalize the values and cultural norms contained in regulating the life of the community. The type of method applied in this research is descriptive qualitative and literature study, which is sourced from research results and publications. Another source taken is stories from the people of North Bengkulu, namely from the people around the city of Arga Makmur. This story is obtained through discussions, in-depth interviews. Based on the results of this study, it was concluded that the revitalization and preservation of local wisdom in the Rejang Tribe are carried out through the inheritance of local wisdom values, especially those related to understanding why it needs to be done and what its benefits are to the local community. The local wisdom of the Rejang Tribe preserved is in the form of (1) Rejang customs in forest management, (2) mapping of Rejang and Serawai customary forest areas, (3) caring and maintaining the environment in swampland processing for rice farming, (4) subak (a traditional water management system) in the north Bengkulu regency, (5) caring and maintaining processing, indigenous farming, Rejang and its goals), (6) cayo source law, (7) earthquake-resistant Bengkulu traditional house technology, and (8) village washing traditions.
\end{abstract}

Keywords: Revitalization; Conservation; Preservation; Local Wisdom; Environmental Education

\section{Introduction}

Indonesia is a nation that has great cultures with the values of local wisdom. As a multicultural country, Indonesia has abundant traditions and local wisdom values which are needed to be preserved as the negative influences come from outside (Rukiyati Sugiyo \& L. Andriani Purwastuti, 2017). Wisdom has been ingrained in people's hearts. The good values have taken root, become the philosophy of society, and transform into local wisdom (Kartika, 2016). Indonesia is also a country that has a varied culture from different tribes as an asset of intellectual and culture. According to (Sholeh et al., 2019) state that culture can be divided into national culture and local culture. Based on the statement from (Hery Gustini Nuraini and Muhammad Alfan, 2013) state that national culture is a culture originating from local culture or regional culture throughout Indonesia, which is appropriate and in line with norms and values as a guideline for the life of the nation and state. While The term local culture is commonly used to characterize the experience of everyday life in specific, identifiable localities. According to Toharudin \& 
Kurniawan (2017) state that Local wisdom is the hallmark of a particular area or region that has cultural value, locally grown in scope from one generation to the next, that is wise, full of wisdom, good value, embedded and followed by members. The variety of cultures can be a potential or challenge to be withstood as a part of cultural inheritance that must be maintained (Hilman \& Sunaedi, 2017). Traditional values of the culture from a different place, time, and community have so much local wisdom which is relevant with the condition nowadays.

Culture is dynamic, continuous to grow, moreover if the potential of the agents of culture is developed and the dynamics are activated through education (Yolles, 2019). So many regions in Indonesia has local wisdom which was caused by the interaction process between human and their environment to fulfill the need of living (Hilman \& Sunaedi, 2017). The experience in fulfilling the need of living has produced various systems of knowledge related to the environment and society.

Local wisdom means a harmonious relationship between man, nature, and the built environment in an area that is also influenced by its culture. (Dahliani, 2015). Local wisdom is one of the products of a cultural community that formed because of the necessity of value, norm, and rule as a model to do something action (Purba \& Siahaan, 2020). Purba \& Siahaan, (2020) state that local wisdom is wisdom in the form of knowledge in certain groups of people in organizing social life and adapting to the environment that is passed down from generation to generation. Concerning this concept, (Kartika, 2016) describes the essence of the relation between humans and their natural environment as united by human cultural patterns.

Bengkulu indigenous community as indigenous community is still applying the tradition in which the caretaker and the leader of the community are doing surveillance. Community obeys the rules as a form of reliance to their customers as a taboo that should be run and faith to the existence. The belief in the taboo and magic power is still alive in the entire community.

The local wisdom of Bengkulu Province has a function as a social institution that can control the manner of humans in the interaction process with nature and other human beings. The meaning and function of local wisdom is a general guideline or principle adopted by every member of society, especially in attitude and behavior, to meet social needs (Purba \& Siahaan, 2020). Therefore, value is an idea related to what is considered good, worthy, and desired by all levels of society in life.

A cultured human is a human who has had control and acts following cultural values especially ethical values and morals that exist in that culture (Bintarto \& Hadisumarmo, 1982). So that, someone who developed appropriately with their culture is someone who also developed his/her education since they have the same purpose in personality development in the culture that the education occurs.

Education is a process of civilizing and a tool for cultural change. This process occurs in any form of inheriting cultural tradition from one generation to the next generation and through the process of cultural tradition adoption for those who have not known the culture before.

Cultural values and local wisdom need to be developed as an integral part of education from any kind and stage. The development of local wisdom education will not be carried out well without optimal participation from the community. Bringing everyone and every unit of the community to take part and being the organizer of the education program is a worthy contribution and should be given attention and appreciation. The principal duty of education is inheriting cultural value following the potential and environmental conditions.

In this case, Goldberg (2010) stated that education with a cultural base is a strategy of creating a learning environment and planning the experience of learning which integrates culture as a part of the learning process. Through cultural base education, student and the community not only imitate and/or accept delivered information but also create sense, comprehension, and meaning from information they 
have accepted. Tilaar (2000) view stated that basic education, community, and culture are single tripartite. It has meant that culture is basic, while the community is a provider of the facility, and education is an activity that conserves and develops cultural values which bind life together in the community. In this case, the community is the owner of that culture.

Local wisdom that exists nowadays is facing a challenge that threatens its preservation so that it begins to erode by the development of technology, which has an innovation adoption process and the diffusion of technology adoption. The other factor is the quantity of inhabitant, poverty, and social gap. To anticipate the problems, local wisdom which is prevailed in the community hereditarily and has a close relation to environmental sustainability should be preserved by understanding the local wisdom becomes an important thing in natural resource management and conserving the environment.

Research about the local wisdom role of the Bengkulu community in environmental education with using nature as a facility is important to do to get holistic comprehension. Local wisdom as an object of the research is holistic because relates to knowledge and comprehension about entire life with all relationships in the universe.

\section{Method}

The type of method applied in this research is descriptive qualitative and literature study, which is sourced from research results, publications, and community stories. This local wisdom was obtained through in-depth discussions and interviews. In the form of an in-depth interview, researchers make an effort to collect and analyze non-numerical data to understand the community's concepts, opinions, or experiences. In the process of study, researchers emphasized on excavate information through thorough inquiry toward the local community, sharing with the community, talking about how to empower the local community, and carrying out useful planning for the local community.

The object of this research was the local wisdom of the Bengkulu community to develop the reconstruction of cultural values and the local community. The object of this research was about local wisdom that has a role in living environmental education. For this research to produce a comprehensive study, researchers determine the research location which has and applies local wisdom to love, take care of, and preserve environmental local with descriptive qualitative, participatory planning and research methods.

\section{Finding and Discussion}

The result of the research shows that revitalization of local wisdom in environmental education can be elaborated from adaptive behavior using unique steps in facing an environmental problem, as follows:

\section{Rejang Customs in Forest Management}

The Rejang tribe inhabits the mountainous area which is currently located in the districts of Lebong, Rejang Lebong, Kepahiang, and Central Bengkulu. Although there are also Rejang tribes living in the coastal areas of North Bengkulu Regency, from Kerkap to Serangai. The Rejang tribe in the mountains, their lives are very dependent on forest products. From generation to generation, a lot of local wisdom has been adopted by the community. The Rejang tribe occupies Rejang Lebong district, Kepahiang district, North Bengkulu district, Central Bengkulu district, and Lebong district. The Rejang tribe is included as one of the tribes as the cultivator in the form of shifting cultivation. As part of the indigenous community, which is integrated with the forest ecosystem, the Rejang tribe indigenous community has local wisdom as an effort to preserve the area which is managed based on the principles of democratization and sustainability. There are some local wisdom of the Rejang tribe in forest management are as follows: Taneak Tanai, Utan or Imbo Piadan, Adat Rian Cao, Mengeges, Ali Bilai, Bo 
or Silo, Sakea, Jamai, Meniken, and Sorongan. Most of the local wisdom is still adhered to by the Rejang community. Some of the local wisdom is:

Taneak Tanai is a term for a stretch of land within the scope of a communally owned customary community and is usually part of the community's management area, there are consequences for individual ownership in the taneak tanai area where each party who manages a certain area within the taneak tanai is obliged to plant crops-hard plants that have conservation and economic value such as petai, durian, etc. as a sign that the area has been owned by a certain person and family.

Utan or Imbo Piadan, is the name for a forest that is believed to have a magical guardian so that there are several prerequisites to open this area, there are rarely people who dare to open this forbidden forest. In the Rejang tribe area, called Jurukalang, the exact name is in Bukit Serdang Area is an area that is believed to have supernatural powers that maintain the area. The tribe has local wisdom called Adat Rian Cao. It is a customary procedure or local term to mention local wisdom, this customary procedure develops according to the needs and development of the community members.

The felling of honey trees, which is called sialang, is a severe taboo to do. If the tree is still cut down, it will be subject to a half-build fine or half the penalty for killing people. Likewise, cutting down the trees around the Silang tree is also considered a customary taboo. Sialang is considered a communal right and when harvested, it is usually known by the entire community. There is a certain part of the harvest that should not be taken and left to live around the tree because it is considered the supernatural guardian rights of the tree. The harvest process is also accompanied by songs of praise, both praise to the wood and praise to the watchman.

Kedurai is one of the traditions that is believed to be a place of communication between humans and supernatural powers, several types of kedurai are often carried out by the community. In Rejang Tribe, Jurukalang, kedurai to open plantation land in a forest in a certain area is a process of requesting permission and safety for those who manage it. Kedurai Agung, Grand Kedurai, is usually done when there is a warning by the supernatural in the form of Bumai Panes, this Kedurai process is carried out by a shaman called Pawang. Kedurai is a mystical event that is practiced by the Rejang Lebong community as follows. Kedurai Agung is a hereditary tradition carried out by the Rejang Indigenous people to communicate with their ancestors. In this communication, people will ask their ancestors to protect them from various disasters. Both natural disasters, diseases as well as pest and disease attacks on livestock and plants. "It is held on the 16th day of the month of Apit. The Apit Month is the month of the arrival of various pests and diseases that attack humans and other creatures. Quite a lot of materials and tools are needed in organizing the Kedurai Agung. Such as threads of 3 colors, namely black, red and white as long as 3 hand spans plus 9 times 3 parents' fingers and rolled up, 99 limes, 99 cloves of cigarettes, three types of flowers (rose, Cempaka ivory, and cepiring), including Cempaka, rose and jasmine, ripe betel leaves and raw, 9 pieces each, 198 grains of turmeric rice for sprinkled and 19 grains for offerings, 3 segments of bamboo sticks, one of which is filled with coconut water and the other is filled with coconut milk, and three-colored threads (white, red, and black). Blood and liver and heart of a 2-month-old chicken. Part of the liver and heart was cooked. Other ingredients for the Kedura event are 1 arbor of turmeric rice and 9 large Sabai cakes and 99 small Sabai cakes. While the equipment for carrying out this event is 1 random piece (where the offerings are placed) made of 1 segment of a bamboo stem which is split into two parts and each part is divided again into 9 parts and arranged to form a square. The other equipment is 1 sungea (random place) made of 1 bamboo segment which is split into 4 but does not come off, and each end of the split bent to the ground. Apart from the others that are no less important, there is 2 takia (blood containers) made of bamboo, an arbor cover, and several other pedestals made of banana leaves. In seeing all this done together. However, for cooked ingredients, the cook should not be careless. The selected cooks are young men who are not married or mothers who have not experienced menstruation anymore. The implementation of this kedurai is led by the descendants of the kuncen interpreter, who sits on his left side 2 girls and 2 bachelors, and in front of him are the ingredients needed. 
Mengeges is a habit of the people in Jurukalang to clear their cultivated land by burning it, this is actually to prevent the fire from spreading everywhere, in the process of burning land it is usually done in cooperation. Ali bilai is the mention of cooperation in completing one of the residents' jobs, in turn, Bo or Silo is a kind of prohibition sign or a sign of wanting to have immature forest products, namely a stick of bamboo that is stuck into the ground, the top of which is split in two and between the fragments is another bamboo. Sakea of cultivated land that has reshaped the forest, usually people Rejang in Jurukalang return to Sakea when their land is not fertile, this is often referred to as shifting, and outsiders who stigmatize indigenous peoples often refer to this as shifting cultivators. Jamai is the state of the land left after harvesting or the state of the land that has been cultivated and deliberately abandoned so that it becomes forest again. Meniken is a ritual activity or feast for clearing land that will be cleared for cultivation or arable land. Sorongan, is the leasing of uncultivated land to other people, with rents from the agricultural land.

In addition to some local wisdom in managing the environmental sustainability of the clan, there are several other prohibitions, wood which if cut down then forms a bridge on both sides of the springs on both sides is prohibited to be cultivated, there is a local belief that if cultivated will cause danger and disaster for the owner, in the modern conservation system on both sides is called the river spadan. Likewise, land which when the logs are cut will slide far due to the steep slopes is also forbidden to cultivate. Telun areas and waterfalls are also prohibited from being managed by community members because it is believed that there is a supernatural influence around the area. Springs and waterfalls are prohibited areas because there are springs that must be protected.

Cutting down the "honey tree" which is known as Sialang is a severe taboo to cut down, if it is cut down it will be subject to a fine of half wake-up or half of the fine for killing people, as well as cutting down the trees around the Sialang tree is also considered as a customary taboo. Sialang is considered a right communal and when harvesting it is usually known by the whole community and there is a certain part of the harvest that cannot be taken and allowed to remain around the tree because it is considered that part of the harvest is the invisible watchman right of the tree, the harvest process is accompanied by singing praise both the praise of the wood and the praise of the watcher.

Apart from supernatural influence, there is also a watchman called Mak Somai who oversees the area. Mak Somai is an invented tiger who is believed to be the guardian in the area. This is a form of local wisdom in the framework of preserving trees and conservation areas, such as springs and waterfalls which are very useful for forest preservation. Magical stories, as well as legends, were very effective in ancient times to protect the area.

Apart from some local wisdom in managing the environmental sustainability of the clan, there are several other prohibitions, including wood which, if cut down, forms a bridge on the two sides of the spring, both sides are prohibited from being worked on. There is a belief of the local community that if the two sides are worked out, it will cause danger and disaster for the owner. In modern conservation systems, these two sides are called river borders. Likewise, land, when the wood is cut, will slide away due to steep slopes which are also forbidden to work on.

The local wisdom of the Rejang tribe in the form of "Taneak Tanai, Utan or Imbo Piadan, Adat Rian Cao, Mengeges, Ali Bilai, Bo or Silo, Sakea, Jamai, Meniken, and Sorongan" is basically to effort in forest management. All of them have purposes to protect and preserve them from damage.

\section{Management and Mapping of Rejang Customary Forest Areas}

The Rejang tribe has the wisdom of zoning forests, they have determined imbo lem (deep forest), imbo u'ai (young forest), and pinggea imbo (peripheral forest). In their zoning, there are rules about planting and logging. In the Rejang tribe, there is a typical farming community, has also developed local wisdom in clearing fields called "celako humo" or "disability humo", wherein opening fields they see 
signs of nature before opening fields where there are the seven taboos, the seven taboos if they are violated, one of them will result in nature and its penunggunya (supernatural beings) will be angry and spread disease. The seven taboos are (1) ulu tulung buntu, it is prohibited to open fields in the forest where there are springs; (2) surfing the boat; (3) deer repeating tai, (4) bronze tiger; (5) grilled tongs; (6) the father waits for the child; and (7) waiting for the cupola.

All of the above illustrates how the Rejang tribal community carries out environmental management through local wisdom. Environmental management through local wisdom is considered to play an important role because it refers more to the practices, knowledge, values, and beliefs of individuals in developing an environment historically, conception, and perception by local people (Richeri et al., 2013). The need to integrate local wisdom and conservation efforts of natural resources because it is a manifestation of the concept of thinking about the environment so that it becomes the capital of understanding on the quality of biological resources in a sustainable manner (Henri, Hakim, \& Batoro, 2018). The balance of the environment needs to be maintained with high awareness by the local community, in its way following the mindset and traditions that took place in its time has been able to create ways to preserve the balance of the environment (Triastianti, Nasirudin, Sukirno, \& Warsiyah, 2018). More precisely this local wisdom is called the traditions that exist in the community where every action or action that is usually carried out is following the rules that exist in the community itself (Francis, 2015). However, local wisdom in various regions has similar functions as guidelines, signs as controllers to behave and interact with nature (Fauzi, 2013). Yamami (2011) expresses local wisdom in the form of knowledge, norms, ideals, values, skills, experiences, behaviors, habits, regulations in a region to meet the needs of living together passed down through generations in the conservation of their living environments.

Moral values which are contained in the instilling principles to love the environment could be used as a basis to manage the environment continuously because it contains principles: the eternal values, friendly environment, the awareness of ecological, and care about social life, especially values of how to choose which of the forests are better to be managed, safely cultivated and conserved. Instilling an attitude that loves the environment is an important thing to create behavior patterns to be friendly nature.

\section{Caring and Maintaining The Environment in Swamp Land Processing for Rice Farming.}

Caring for and maintaining the environment is an important thing to do by the community to create a conducive environment. Like what Soemarwoto (1983) said "managing the environment can be meant as an effort to maintain or and to improve the quality of the environment so that the primary need of human being could be fulfilled as good as possible.

Keeping the cleanliness of the environment is the implementation of cultural adaptation by the Rejang community and some other Bengkulu communities. Generally on caring and maintaining the environment. This technology was initially not interesting to write about because it seemed "lazy" by residents of Java. But after learning the tillage minimum tillage technology and also no-tillage, the technology is correct.

Until now, there is no technology capable of dealing with it in lowland swamps (valleys). The success of rice cultivation in lowland swamps is largely determined by local weather conditions and the surrounding area, especially the upstream area, which will have a direct effect on swamp water conditions. Swamp water that recedes slowly will make it easier for farmers to determine the right planting time, but on the other hand, swamp water that recedes fluctuates irregularly due to very fluctuating rainfall will make it difficult for farmers to determine the right planting time. Choosing the location and determining the timing of planting that is not right, especially for planting rice during will bring the risk of crop failure due to exposure to water attenuation due to rising swamp water. 
This local technology provides enormous benefits for the preservation of nature and the environment. But nowadays it is rarely encountered, people prefer to use technology that is said to be advanced but not friendly to the environment. Planting activities which are local wisdom technology are as follows:

\subsection{Selection of fertile land}

In carrying out farming activities in swamps, farmers choose promontory land or land close to rivers, because the area always receives fertile silt, which is marked by loose black soil, and has been overgrown by types of water bodies, such as Kiambang (Salvinia sp. ) Enceg goiter (Elchornia sp) and other characteristic signs.

Based on the results of the study, it is known that the two types of aquatic plants grow well at a $\mathrm{pH}$ above 4, and less well at a $\mathrm{pH}$ of less than 4 . In addition, transportation from the residence to the rice fields is easier to go back and forth, especially for product transportation activities. Therefore, almost all areas of shallow swampy land have been cultivated for agriculture.

In North Bengkulu Regency, there are still many small rice fields located on the banks of small rivers or swamps. Currently, the swamp has been processed more technically. The government has helped by building irrigation weirs so that the character of the swamps has been transformed into semi-technical and technical irrigated rice fields. The location is much more fertile than the rice fields that have been touched by modern technology.

\subsection{Cropping Pattern}

The cropping pattern was initially fallow because the varieties planted were long-lived. Currently, the cropping pattern applied is the rice-paddy-fall (unplanted) cropping pattern. The community has lost a lot of local rice and has been replaced by short-lived national superior seeds. However, with the many intensification programs that have been introduced, some of the broad expanses have implemented a ricerice-rice cropping pattern. In this area, it is a bit difficult to change to paddy-rice-crops. The planting season begins in the rainy season. The rice-fallow cropping pattern is still being applied by the community along the Air Lais river (one of the sub-districts in the North Bengkulu Regency). This is done based on the relative shortage of rice. So that you can plant rice 2 times a year.

Besides adjusting the season, this cropping pattern is also effective in improving soil fertility and controlling pests. For example, the experience in Rejang Lebong Regency that planting rice and being felled (not planted) or used for mina (fish livestock) was more effective. This cropping pattern is local wisdom that is starting to erode because of the interest in pursuing production. Farmers provide opportunities for the land to improve itself, by allowing grass to grow, and also the process of rotting the remains of rice stalks.

The economic conditions of the people during this fall were not disturbed. Farmers have another source of income, namely rubber. A diversification pattern that supports people's economic resilience. So that the Rejang rural community has food security. The source of food is not only from the fields but also from the fields. When the rubber plantation land is still able to be planted with rice, then the field rice plant is cultivated.

\subsection{Land Preparation}

The land is prepared by slashing using rimbe. Namely, a slashing tool that is swung like a hoe, the direction of the swing is from right to left. The use of this tool is no longer available today and has been lost to herbicides. The slashing is carried out while the swamp water is still deep. Once in the tripe, the grass is collected in the embankment. The clean and open land provides an opportunity for the 
development of water plants of the type of Kiambang or Kai Apu (Salvinia mollesta) and Salvinia Natan), aquatic plants that have two reproductive methods (stolons and spores) and grow rapidly covering the land.

This local wisdom gives rise to a fairly wide and thick expanse of the population of Salvinia sp. The stretch descends to the ground when the water begins to dry out, with a dense population and a thickness of up to $15-20 \mathrm{~cm}$. Then the farmers plant rice seeds on the Salvinia expanse, the plants will grow well and Salvinia will become an effective mulch to control the rate of evaporation of groundwater, effective weed control, and as a source of additional nutrients.

Another method of slashing is to form an elongated path, or in the form of a pile of grass slashed. After the planting activity is complete, the rotten grass as a result of the slashing is spread back between the planting rows, as organic mulch/pupu. Local wisdom is now being applied to the SRI method of rice planting technology which is currently popular. People in Bengkulu and also in Kalimantan have been doing it from generation to generation.

Farmers do not cultivate the land such as hoeing or plowing the land. It turns out that at this time it is only understood that this traditional technology is more friendly to the environment. This method does not damage the structure of the swampland, which is mostly peatland. There is no oxidation which increases the acidity of the soil and also does not result in the release of methane gas into the air from soil processing activities on peatlands.

\subsection{Planting Activities}

There are two ways of planting rice. First, using a nursery, then transplanting it. Second, they do not use a nursery but plant the seeds directly on the land by burying them into a swamp that is not too deep. The first method is more widely used.

In carrying out lowland swamp rice cultivation, farmers will start work in the rice fields based on natural signs, including if among the trees (generally swamp mango or rerawa) there are many stretches of insect white tendrils, and dadap tree-like trees have begun to develop, is one a sign that the dry season will soon arrive. So that the farmers will immediately prepare the nursery and land preparation. On the other hand, if the rivers have started to see the development of the Seluang fish (Rasbora agyrotaenia), a type of small fish typical of Kalimantan and Sumatra, this is a sign that the rainy season is coming soon, so the preparation for paddy rice cultivation must begin immediately.

\subsection{Population Planting}

Cultivating rice is swollen land that is already very existing is using local superior varieties, namely varieties that have adapted very well to lowland areas because they have been cultivated for a long time. These varieties are generally deep, and plant height is generally $90 \mathrm{~cm}-120 \mathrm{~cm}$ or more. This plant height is adapted to water conditions, especially for rainy season cropping in shallow swamps. This variety has a high maximum number of tillers 20-35 tillers/clump, with a spreading canopy type, so that not all tillers are successful in forming panicles due to high respiration so that the net photosynthesis is low. To get good results, farming communities generally have guidelines for the population per hectare, which is translated into spacing, which is what is known as the "four sedepa" planting system, meaning that in sedepa length equivalent to $1.7 \mathrm{~m}$ planted 4 clumps of seedlings, which, if the distance is equilateral, the plant population will be equivalent to 55,363 clumps/hectare. This population has been exercised for a very long time and has been hereditary. However, in the development of agriculture in lowland areas, the population is considered to be insufficient so that a special effort program has emerged, the "sedapa four" planting system has been changed to the "sedepa lima" planting system, or "sedepa plus one" and the last one was the "two nine planting system "Which means that in two fathoms 9 clumps are planted. The planting population is indeed rare but has scientific value because of the high shoots and the 
spread of the canopy, so that plant science in terms of distribution of sunlight and plant form has been owned and applied by smallholder farmers for a long time. It is not an exaggeration to say that Indigenous knowledge, local wisdom have inspired the emergence of the "legowo system" (lego and dowo), "habas" (free air), and others that have developed so far.

A lot of local moral values wisdom which is contained in caring for and maintaining the environment in swampland processing for rice farming. Those are how to select fertile land areas, how the cropping pattern should be conducted, how should we do land preparation before planting it, and how planting activities should be conducted to get good results. In short, the values which should be instilled into the young generation are how to bring the young generation to think effectively before doing something.

\section{Subak (a Traditional Water Management System) in North Bengkulu Regency}

Subak is a traditional water management system that has been around for centuries but is still alive today. This subak (developed by Balinese in Bengkulu) is closely related to Hindu religious activities and water management activities. So that local wisdom is closely attached to water management for agriculture where there are Balinese Hindus.

Even though the Balinese in North Bengkulu has mingled with various tribes and regions, and have long since left their hometowns, Subak activities are still preserved. Not all Subak members are Balinese, but whoever owns the land in the area.

Subak activity areas are determined based on the extent of the area that can be irrigated by irrigation weirs. Because the location of the existence of local wisdom is the majority of Balinese people, in one dam a Bedugul was built as a place of worship for the god Baruna who maintains and protects water. The weirs in this area come from small rivers which are built by check dams. There are 3 subaks in Arga Makmur District. Subak Tirta Gangga in Sido Urip Village - Rama Agung, Subak Rama Dewata in Rama Agung Village, Subak Tripugar Baru in Taba Tembilang Village. The largest Subak group is Subak Tirta Gangga.

Each Subak is led by a Klian Subak (chairman/priest). This is what determines when to start planting. Customarily at the beginning of planting, cleaning of irrigation channels and checking dams is also carried out. This activity is carried out by cooperation among members of the Subak. Gotong royong is coordinated by Ulu-ulu, who is also in charge of regulating water. The distribution of water is determined based on the area of land owned by the members.

Based on field observations, this subak group is more orderly and obedient to meeting schedules, compared to other farmer groups. Meetings are held once a month on a certain date that has been agreed upon. At this meeting, it usually discusses the problems of its members, especially in the distribution of ulu-ulu water, payment of monthly fees, and also savings and loan activities that utilize group cash. Participants who took part in this meeting were all farmers in a stretch that was affected by drains in the subak area. Not limited so that it does not look at certain religions, beliefs, or ethnicities. This is different from other farmer groups, whose meetings are when there is assistance or are requested by extension workers. In this Subak group, extension workers or officers from the Agriculture Office must adjust their schedule to be able to meet with the group members as a whole.

The distribution of water is determined based on how many pods are needed. Pods are a term for pipes or channels from irrigation to land. The number of pods describes the required water discharge. Determined based on the area of land or its use. The number of pods will also determine the obligation to pay the group monthly fee. 
If there is damage or routine maintenance, cooperation is carried out to repair the dam and irrigation canals. Damage often occurs, such as broken embankments, landslides, or fallen trees that block irrigation channels. This cooperation agreement is determined by the head of the subak chairman. If someone is unable to attend, he will be subject to a fine. This cooperation obligation is determined based on the volume of water pods. If a member of this group has two stretches of rice fields, then he must send 2 people to join the cooperation. Usually, the father and son participate in cooperation. If he is unable to do so, he will have to pay a fine. The payment of this fine also applies to people who are no longer able to work hard, such as old people or widows. Payment of this fine is several payments for the benefits of water for one year, which is paid for three months (following the harvest).

Regarding the application of rights as well as sanctions, whether it is a fine or a contribution obligation, there is often quite a heated debate. If the sanctions given are not heeded, then the risk can be excluded from the group. At this time a clan (the head of the subak) became the mediator and decisionmaker for disputes. So far, the decision of a subak clan will be obeyed by all members. Because they believe that they will get balak, or karma nutmeg as a result of that opposition.

Subak group members may not participate (not be active) in activities related to cooperation to repair waterways if they are planting crops. However, they still pay the group's monthly contribution obligations. He still has the right to participate in group savings and loan activities. If you are already in the field again, you can join as usual.

\section{Caring And Maintaining Processing, Indigenous Farming, Rejang, And Its Goals}

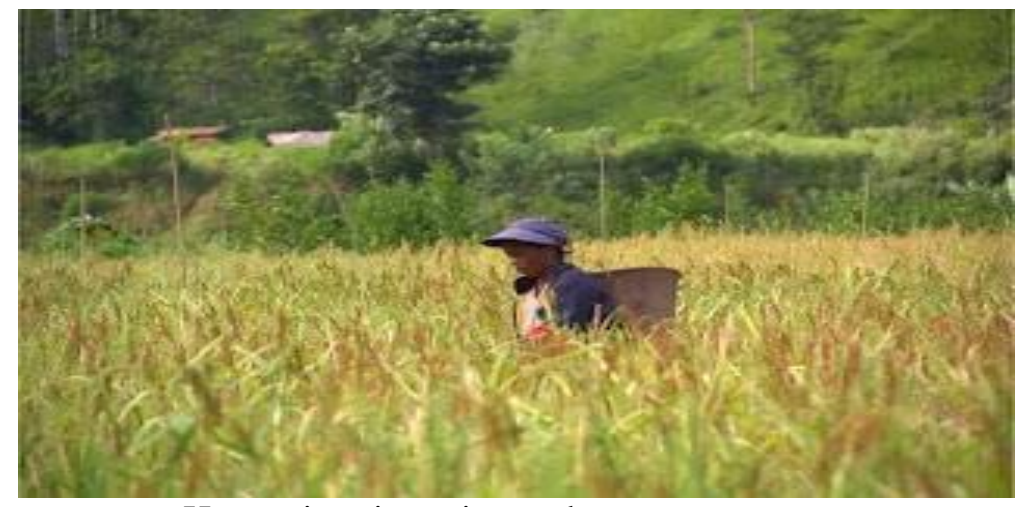

Harvesting rice using crabs

The procession of cultivating the fields according to the Rejang customary law (one of Bengkulu tribes), begins with the process of selecting land for farming, clearing the forest, and rituals before clearing the forest. The ritual is led by a traditional elder (dukun), the ritual functions as an expression of excuse or asking permission from the ancestors of the ancestors to open clan land. The procession of farming in the fields is still in use today from the traditions of our ancestors, believing that the procession before opening the field will avoid all things that are not desirable.

Those involved in the procession of farming in the fields according to Rejang customary law are the shaman and the family concerned as well as people who help in cleaning the fields. According to the beliefs of the Rejang community in the Lebong Regency, people who do not carry out processions of cultivating fields, according to Rejang customary law, usually have difficulty in farming or get disasters, such as poor crop yields, disturbed by spirits. In essence, the pre-farming procession is carried out to avoid unwanted events. 


\section{Earthquake-resistant Bengkulu Traditional House Technology.}

It turns out that the house built by the Bengkulu people is a stilt house with a predominantly wooden structure. Earthquake-resistant houses with extraordinary technology. I quote this paper from the research results of Triyadi et al. (2010) regarding the Bengkulu Vernacular House Building in response to the earthquake. The research was conducted in Duku Ulu Village, Curup Timur District, Rejang Lebong Regency. This research was motivated by the ability to survive Bengkulu traditional houses against earthquake disturbances in 2000 and 2007. So it is hoped that this technology can be preserved and can be included in the design of house construction in Bengkulu Province.

In principle, there are two kinds of Bengkulu traditional houses, namely the Rejang vernacular house and the Malay vernacular house. The Rejang vernacular house originating from or originating from the traditional Rejang house (Umeak Potong Jang or Umeakan) has been influenced by the shape of the Meranjat house (the form of the tribal house in Ogan Komering Ulu, South Sumatra).

The size of the Rejang vernacular houses in Duku Ulu Village has an average width of 6 - $7 \mathrm{~m}$ and a length of $15-17 \mathrm{~m}$, and is rectangular in shape, with a regular division of internal space. The floor of the building is on stilts with an average height of $2.20 \mathrm{~m}$ (the space under the stage floor can be passed by people without the need to bend down). This vernacular building uses local wood materials (medang kuning, medang batu, balam, etc.) and several additional parts of the building use bamboo (serik bamboo, menyan bamboo, dabuk) for the floor of the building. The floor of the building is supported by columns or pillars from wooden beams (logs $\varnothing 40 \mathrm{~cm}$ or wood 20/20) and poles above the stage floor and above measuring $10 / 10 \mathrm{~cm}$. The walls of the building are made of wooden planks $\pm 2 \mathrm{~cm}$ thick. For roof covering using zinc.
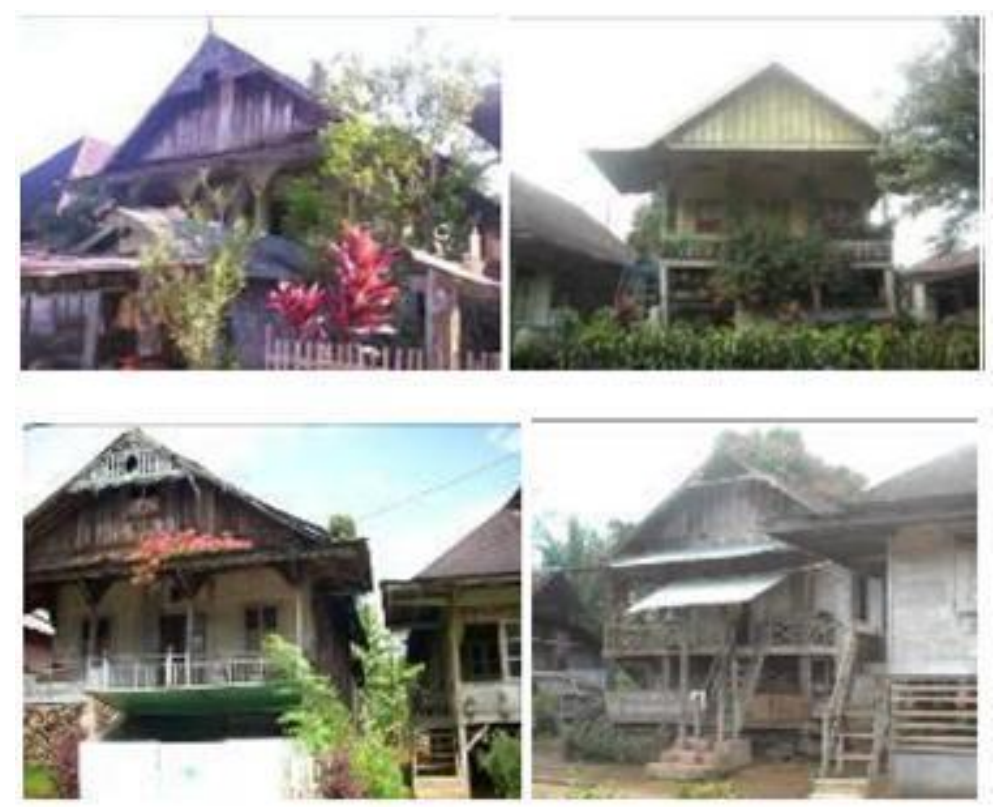

All connection systems for building structural components and building construction use a papurus connection system, male (betino-lanang), do not use nails (except for floor coverings and part of the walls) but use wooden or bamboo pegs. The walls use wooden planks that are clamped on top and bottom and certain charts, like the kitchen, have used nails. 


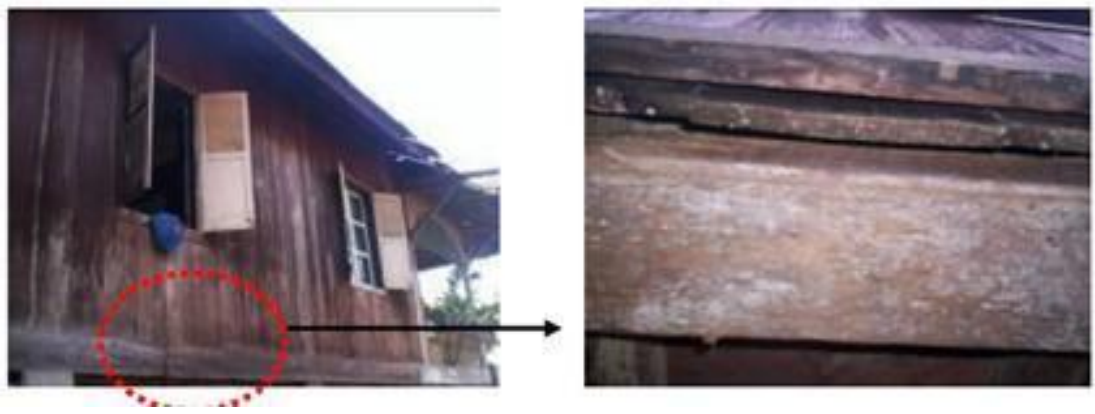

The foundation of the Rejang vernacular house building in Duku Ulu Village is in the form of a stone base, masonry, and even some stilt poles have been turned into concrete columns or brick pillars, if an earthquake occurs it is quite strong considering the large dimensions used. Likewise, the relationship between the foundation/stage column and floor beams is the joint support, so that if an earthquake occurs, the floor of the flexible building moves so that the building as a whole is not damaged.

The building floor is a structural system that integrates with building poles that have no direct connection with the stage poles (not continuously from the stage poles to the building poles on the top floor). The floor frame is directly related to the main column of the building, the wall frame beams. Likewise, the main walls and columns will meet the ceiling frame with the ceiling and the roof system of the building.

The building material used in the Bengkulu Rejang vernacular house in Duku Ulu Village uses the main wood material, either wood that is still in the form of blocks/logs or that has been sawed off. For roof coverings use a lightweight material, namely zinc.

The use of wood and zinc roof covering makes this building a light building, so that when an earthquake occurs, the building only shakes and does not collapse. The choice of material and the method of installation in this building is the right indigenous knowledge to anticipate frequent earthquake disasters.

Every Sunday, the indigenous community cleans Jalan Setapak (little path) in the middle of the sacred forest from the gate to the Pamekaran crater. It reflects togetherness value and mutual assistance value still exist. Kuta community still has a sense of responsibility, especially on conserving the forest it can be seen from their effort to take their time and their energy for that activity.

The obedience of the community to the customary rules, they clean the path only using a broom made of such splintered ribs, wood, and bamboo. It makes the path in the forest always look clean and natural. The community is not allowed to use tools made from iron such as mattock, sickle, machete, etc., because they are afraid it would destroy the condition in the forest. They realize wickedness happens when there is an opportunity and aim, so no matter how slight the opportunity, it has to be avoided and obey the rule.

The culture of cooperation to clean the forest makes the cleanliness of the forest is maintained well. It makes it the people who want to visit the forest easy to walk on the path. Besides that, to keep the totality and forest conservation, every month, caretakers and some indigenous communities are doing patrols surrounding the sacred forest. It has a function to take care of people who want to destroy the forest or steal the wood (cut the trees).

Local wisdom in this community is important to take care of and conserve the environment. Not only aware but also morality and spirituality belief if human beings live and unite with nature. It will emerge harmonization and give benefit to each other. 
This condition has the same argument as what Bintarto (1982) said that human beings as an individual or groups live in the nature and environment. From the close relation and reciprocal, a human being takes some adaptation, even the human being do conservation.

\section{Cayo Source Law}

The cayo source law that is widely applied in Bengkulu, from the Rejang, Serawai to Pekal tribes around Ketahun, Napal Putih, and Mukomuko, is about livestock grazing and garden maintenance. One of the laws of cayo sources that is often expressed is "Garden Cages Day and Livestock Cages Night". In the $80 \mathrm{~s}$, this law often triggered conflicts between transmigration and non-transmigration residents.

The implementation of this law is for livestock owners, it is obligatory to make cages and cage their livestock at night. Likewise, the owner of the garden is obliged to build a pen (fence) that protects the garden from disturbance by livestock during the day. The demand from livestock owners is that if damage to crops in the garden occurs at night, the livestock owner will be compensated for the actions of his pets. However, if the damage is caused during the day, then the owner of the garden cannot claim compensation, because he is obliged to look after his garden and also fence it off.

Along with changes in community gardening patterns, this law is now starting to fall into disuse. The natural rubber has been replaced with superior rubber and oil palm plantations. In addition, local regulations have been enacted relating to the obligation to house livestock, so that livestock are not allowed to roam on roads that endanger road users.

According to pekal community leaders, such as Jamari AS Jamal, why the cayo source law was passed by the Dutch was because it benefited the Netherlands and the community's elite at that time. The buffalo owners, numbering up to hundreds, are pesirahs and aristocrats who submit to the Dutch. Meanwhile, most ordinary people are farmers. It is a heavy burden for farmers to protect their gardens. If they are damaged by the livestock of pesirah and aristocrats, the farmers cannot file charges.

The obstacle when the livestock is housed is that the owner has to provide feed. This is what the community cannot do because they consider that action to be enslaved by animals. So that the cattle at home are not effective in running, eventually they have to be sold. The livestock population depends on the area of the pasture area, the shepherd in the sense that it remains tied several hours later is moved the tying place to a good grass location. Because this location was decreasing over time, the livestock was decided to be sold.

Raising livestock utilizing a night pen and day "diangon" (tied to grassy land) persists in people who have adapted to the pattern of raising livestock in transmigration communities who are accustomed to mowing grass for animal feed at night.

\section{Village Washing Traditions}

The washing of the village is a ritual of rejection of balance, which aims to prevent all villagers from disaster. In everyday life, the village washing ceremony is often found when one of the residents is caught committing a disgrace in the form of adultery in a village. Village washing is a ritual of rejecting logs that aims to prevent all villagers from disasters. In everyday life, we often find village washing events when one of the villagers is caught doing disgrace in the village, especially the disgrace in the village, especially the disgrace that smells of adultery.

Village washing which is rife today is considered by the village community as an effort to preserve customs, but if we understand that people who are affected by this village washing tradition have a very negative impact on their social life because it spreads their disgrace as well as villagers who carry 
out the custom of washing the village will become embarrassed to be seen by other villagers. However, community members become aware of each other trying to maintain the virtues of their village.

\section{Conclusions and Suggestions}

Instilling principles to love the environment is one of the purposes of local wisdom to build the character of the young generation in order has personality and character that love peacefulness and prosperity. The Rejang tribe views local wisdom function as an instrument for personality and good character building, the sign of identity or community identity as an adhesive element in social cohesion, as a base of thinking with the community, and as a basic interaction in community members both internally and externally.

Instilling love to the environment as a form of cultural adaptation process (local wisdom) in environmental education in the Rejang community can be seen from cultural adaptation practice they do by implementing and obeying all of the forms of local wisdom such as doing the recommendation and custom tradition and avoid impolite manner in a form of taboo.

The revitalization and preservation of local wisdom in the Rejang Tribe are carried out through the inheritance of local wisdom values, especially those related to understanding why it needs to be done and what its benefits are to the local community. The preserved local wisdom of the Rejang Tribe is in the form of (1) Rejang Customs in Forest Management, (2) Mapping of Rejang and Serawai Customary Forest Areas, (3) Caring and Maintaining The Environment in Swamp Land Processing for Rice Farming, (4) Subak ( a Traditional Water Management System), (5) Caring and maintaining processing, Indigenous farming, Rejang and its goals), (6) Cayo Source Law, (7) Earthquake-resistant Bengkulu Traditional House Technology, (8) Village Washing Traditions, and (9)Telun and Mak Somai.

\section{References}

Dahliani, D. (2015). Local wisdom in the built environment in the globalization era. International Journal of Education and Research, 3(6), 157-166.

Fauzi, Hamdani. (2013). Pembangunan Hutan Berbasis Kehutanan Sosial (Social Forestry Based Forest Development). Bandung: Karya Putra Darwanti.

Francis, W. (2015). Keunikan Masyarakat Adat (Uniqueness of indigenous peoples). Yogyakarta: Gadjah Mada University Press.

Hery Gustini Nuraini, and M. A. (2013). STUDI BUDAYA DI INDONESIA Heny Gustini Nuraeni Pustaka Setia Buku Original_Shopee Indonesia. CV. Pustaka Setia, 2013.

Hilman, I., \& Sunaedi, N. (2017). Revitalization of Local Wisdom in Environmental Education. 79(Icge 2016), 383-387. https://doi.org/10.2991/icge-16.2017.74

Kartika, T. (2016). Verbal Communication Culture and Local Wisdom: The Value Civilization of Indonesia Nation. Lingua Cultura, 10(2), 89. https://doi.org/10.21512/lc.v10i2.1424

Purba, A. R., \& Siahaan, J. (2020). Meaning and Function of Local Wisdom in the Proverb ( Limbaga) Simalungun. Budapest International Research and Critics Institute-Journal (BIRCI-Journal), Volume 3, 3904-3911. 
Rukiyati Sugiyo, \& L. Andriani Purwastuti. (2017). Local Wisdom-Based Character Education Model in Elementary School in Bantul Yogyakarta Indonesia. Sino-US English Teaching, 14(5). https://doi.org/10.17265/1539-8072/2017.05.003

Sholeh, A., Fadhilah, S., \& Murwaningsih, T. (2019). Character Education Values On Local Wisdom Of Sadranan In Cepogo. https://doi.org/10.4108/eai.27-4-2019.2286780

Toharudin, U., \& Kurniawan, I. S. (2017). Sundanese Cultural Values of Local Wisdom: Integrated to Develop a Model of Learning Biology. International Journal of Sciences: Basic and Applied Research (IJSBAR), 32(1), 29-49.

Yolles, M. (2019). The socio-cultural dynamics of development: part 1 development, growth and globalization. Kybernetes, 49(7), 1813-1836. https://doi.org/10.1108/K-02-2019-0083

Bintarto, R., \& S. Hadisumarmo, 1982, “Metode Analisa Geografi”, Jakarta, LP3S.

Dahliani, D. (2015). Local wisdom in the built environment in the globalization era. International Journal of Education and Research, 3(6), 157-166.

Henri, H., Hakim, L., \& Batoro, J. (2018). Kearifan Lokal Masyarakat sebagai Upaya Konservasi Hutan Pelawan di Kabupaten Bangka Tengah, Bangka Belitung (Local Wisdom of The Community as a Conservation Effort for Pelawan Forest in Central Bangka Regency, Bangka Belitung). Jurnal Ilmu Lingkungan, 16(1), 49. https://doi.org/10.14710/jil.16.1.49-57.

Hery Gustini Nuraini, and M. A. (2013). STUDI BUDAYA DI INDONESIA Heny Gustini Nuraeni Pustaka Setia Buku Original_Shopee Indonesia. CV. Pustaka Setia, 2013.

Hilman, I., \& Sunaedi, N. (2017). Revitalization of Local Wisdom in Environmental Education. 79(Icge 2016), 383-387. https://doi.org/10.2991/icge-16.2017.74

Kartika, T. (2016). Verbal Communication Culture and Local Wisdom: The Value Civilization of Indonesia Nation. Lingua Cultura, 10(2), 89. https://doi.org/10.21512/lc.v10i2.1424

Purba, A. R., \& Siahaan, J. (2020). Meaning and Function of Local Wisdom in the Proverb ( Limbaga ) Simalungun. Budapest International Research and Critics Institute-Journal (BIRCI-Journal), Volume 3, 3904-3911.

Richeri, M., Cardoso, M. B., and Ladio, A. H. (2013). Soluciones Locales y Flexibilidad en el Conocimiento Ecol??Gico Tradicional Frente a Procesos de Cambio Ambiental: Estudios de caso en Patagonia. Journal Ecologia Austral. 23(3): 184-193.

Rukiyati Sugiyo, \& L. Andriani Purwastuti. (2017). Local Wisdom-Based Character Education Model in Elementary School in Bantul Yogyakarta Indonesia. Sino-US English Teaching, 14(5). https://doi.org/10.17265/1539-8072/2017.05.003

Sholeh, A., Fadhilah, S., \& Murwaningsih, T. (2019). Character Education Values On Local Wisdom Of Sadranan In Cepogo. https://doi.org/10.4108/eai.27-4-2019.2286780

Toharudin, U., \& Kurniawan, I. S. (2017). Sundanese Cultural Values of Local Wisdom: Integrated to Develop a Model of Learning Biology. International Journal of Sciences: Basic and Applied Research (IJSBAR), 32(1), 29-49.

Triastianti, R. D., Nasirudin, N., Sukirno, S., \& Warsiyah, W. (2018). Konservasi Sumber Daya Air Dan Lingkungan Melaluhi Kearifan Lokal Di Desa Margodadi Kecamatan Seyegan Kabupaten Sleman Yogyakarta (Conservation of Water Resources and Environment Through Local Wisdom in 
Margodadi Village, Seyegan District, Sleman Regency Yogyakarta). Jurnal Kawistara, 7(3), 285. https://doi.org/10.22146/kawistara.15391.

Yamani, M. (2011). Strategi Perlindungan Hutan Berbasis Hukum Lokal di Eman Komunitas Adat Daerah Bengkulu (Local Law-Based Forest Protection Strategy in [110]Conservation of Natural Resource Management in the Buffer Village Community of Alas Purwo Banyuwangi National Park East Java Indonesia Based on Local Wisdom.

Yolles, M. (2019). The socio-cultural dynamics of development: part 1 development, growth and globalization. Kybernetes, 49(7), 1813-1836. https://doi.org/10.1108/K-02-2019-0083

\section{Copyrights}

Copyright for this article is retained by the author(s), with first publication rights granted to the journal.

This is an open-access article distributed under the terms and conditions of the Creative Commons Attribution license (http://creativecommons.org/licenses/by/4.0/). 